\title{
Breast Metastasis of Esophageal Cancer: A Case Report
}

\section{Özofagus Kanserinin Memeye Metastazı: Olgu Sunumu}

\author{
Havva Yeşil Çınkır ${ }^{1}$, Ülkü Yalçıntaş Arslan ${ }^{1}$, Sultan Çiğdem Irkkan², Fatma Buğdaycı Başal ${ }^{1}$, Ayşe \\ Demirci $^{1}$, Ferit Aslan ${ }^{1}$, Umut Demirci ${ }^{1}$, Berna Öksüzoğlu ${ }^{1}$, Necati Alkış ${ }^{1}$ \\ ${ }^{1}$ Dr. A. Y. Ankara Onkoloji Eğitim Ve Araştırma Hastanesi, Tıbbi Onkoloji Kliniği, Ankara, Türkiye \\ ${ }^{2}$ Dr. A. Y. Ankara Onkoloji Eğitim Ve Araştırma Hastanesi, Patoloji Kliniği, Ankara, Türkiye
}

doi: $10.5505 /$ aot.2012.27146

\section{ÖZET}

Özofagus kanseri, kansere bağlı ölümler arasında 6. sırada yer almaktadır. En sık akciğer, karaciğer ve kemiğe metastaz yapmaktadır. Özofagus kanserinin memeye metastazı nadir görülmesi nedeni ile olguyu sunmayı amaçladık. Ellidört yaşında kadın hasta lokal ileri evre skuamöz hücreli özofagus kanseri tanısı ile kemoradyoterapi aldı. Hastanın takibinde meme dahil olmak üzere yaygın metastaz ile saptandı.

Anahtar Kelimeler: Meme metastazı; Özofagus kanseri; Yassı hücreli karsinom

\begin{abstract}
Esophageal carcinoma ranks $6^{\text {th }}$ among cancer-releated deaths. It commonly metastasize to the lung, liver and bone. Breast metastasis of esophageal cancer is rarely seen and therefore we aimed to present this case. A 54-year old woman who diagnosed with locally advanced squamous cell esophageal cancer received chemo-radiotherapy. In follow-up, widespread metastasis, including breast, was detected.
\end{abstract}

Key words: breast metastasis, esophageal cancer, squamous cell carcinoma

\section{Giriş}

Özofagus kanseri gastrointestinal sistem kanserlerinin \%7'sini oluşturmaktadır. Kansere bağlı ölümler arasında 6 . sırada yer almaktadır (1). Histolojik alt tip olarak en sik yassı hücreli karsinom (SCC) ve adenokarsinom görülmektedir. Hastaların \%50-60'1 tanı anında lokal ileri veya metastatik evrededir (2). En sik akciğer, karaciğer ve kemiğe metastaz yapmaktadır (3). Özofagus kanserinin memeye metastazı nadir görülmektedir. Biz burada lokal ileri evre özofagus kanseri tanisı ile kemoradyoterapi alan, takibinde meme metastazı gelişen olguyu sunmayı amaçladık.

\section{Olgu Sunumu}

Ellidört yaşında kadın hasta bir aydır olan yutma sırasında ağrı şikayeti ile başvurdu. Yapılan üst gastrointestinal sistem endoskopi sonucunda özofagus 24-31 cm'ler arasında yer yer ülserovejetan, lümeni daraltan malign görünümlü kitle saptand. Kitleden alınan biyopsi SCC olarak raporlandı (Resim 1). Yapılan endosonografik ultrason görüntülemesinde American Joint Committee On Cancer (AJCC) 2010 tümör-nodmetastaz (TNM) evrelemesine göre tümör adventisya tabakasını ve çevre dokuları infiltre etmekteydi $\left(\mathrm{T}_{4}\right)(4)$. Sistemik metastaz taramas1 amacı ile çekilen pozitron emisyon tomografibilgisayarlı tomografi (PET-BT) görüntülemesinde; özofagusta lümeni oblitere eden $4 \mathrm{~cm}$ tümöral kitle (Standart Uptake Value maximum (SUVm): 39), paratrakeal, prekarinal, sol hiler lenf bezlerinde artmış tutulum (SUVm: 8.6) saptandı. Genel cerrahi bölümünce operasyon için uygun görülmeyen hastaya definitif kemoradyoterapi (50.4 Gy radyoterapi (RT) ile sisplatin $75 \mathrm{mg} / \mathrm{m}^{2} 1$. gün ve 5 -florourasil $750 \mathrm{mg} / \mathrm{m}^{2} 1-4$ günler 28 günde bir) planlandı. Tedavi süresince hastanın laboratuar testlerinin uygun olmamas1 nedeni ile bir kür kemoterapi uygulanabildi.

Tedavi bitiminden 3 ay sonra kontrole gelen hastanın fizik muayenesinde sağ memede alt iç kadranda $5 \mathrm{~cm}$ boyutunda sert kitle mevcuttu. PET-BT görüntülemesinde; özofagusta çevre vasküler ve parankimal yapılara invaze kitle lezyonu (SUVm: 22.7), her iki akciğerde parankimal nodüller ve plevral kalınlaşma (SUVm: 25), areola düzeyinde iç kadranda $54 \times 40$ 
mm boyutunda kitle lezyonu (SUVm: 23), intraabdominal lenf nodlarında (SUVm: 25) artmış tutulum saptandı. Hastanın sağ memesinde bulunan kitleden tru-cut biyopsi yapıldı. Patolojik incelemede yaygın nekroz içeren ve önceki özofagus biyopsisine benzer geniş eozinofilik sitoplazmalı hücrelerin oluşturduğu, epiteloid adalar halinde SCC görüldü (Resim 2a). Tümörde p63 ve sitokeratin 5/6 (CK5/6) yaygin pozitif bulundu (Resim 2b-c), Gross Cystic Disease Fluid
Protein-15 (GCDFP15) ve mamoglobin pozitifliği izlenmedi. Serum tümör belirteçlerinden karsinoembriyonik antijen (CEA): $1.1 \quad(0-4$ nanogram/mililitre), kanser antijen 15-3 (CA 153): 13 (0-38 Unit/mililitre) idi. Hastaya yaygin evre hastalık nedeni ile palyatif amaçlı sisplatin $80 \mathrm{mg} / \mathrm{m}^{2} 1$. gün ve 5 - florourasil $1000 \mathrm{mg} / \mathrm{m}^{2} 1$ 4 günler, 21 günde bir olarak başlandı. İkinci kür kemoterapi sonrasında hastanın kliniğinde bozulma olması üzerine hasta yaşamını yitirdi.

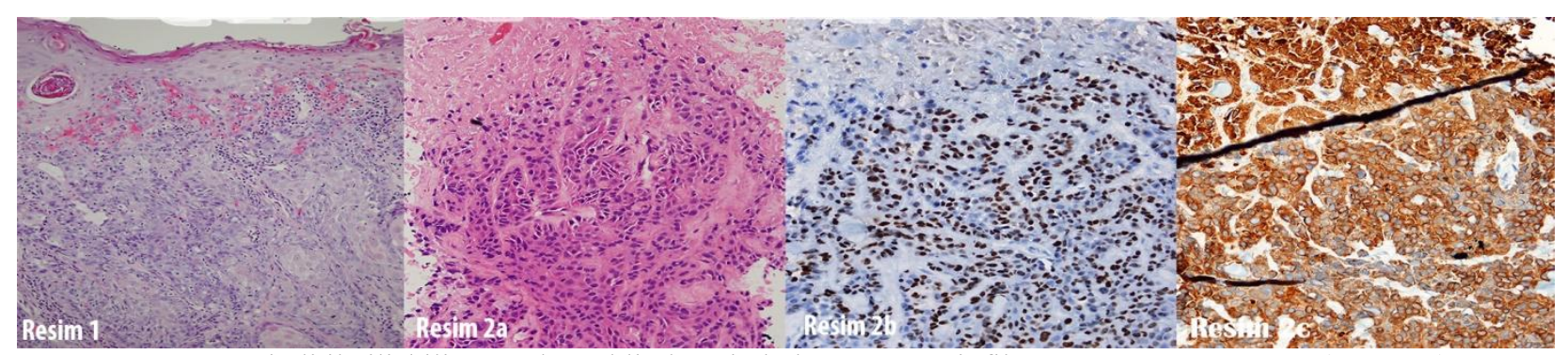

Resim 1: Yüzey epiteli ile ilişkili uzantılar şeklinde epitel altı stromaya infiltrasyon gösteren tümör (HE, x20), 2a: Üst tarafta nekroze özellikte, trabeküler yapılar halinde infiltrasyon gösteren skuamoid epitelyal hücrelerden oluşan tümör (HE, x40), 2b: Tümörde yaygın nükleer p63, 2c: Sitoplazmik CK5/6 pozitifliği (x40).

\section{Tartışma}

Özofagus kanseri insidansı ülkelere, aynı ülke içerisinde bölgelere göre farklılık göstermektedir. Ülkemizde en sik Doğu Anadolu Bölgesi'nde görülmektedir (5). Özofagus kanseri erken evrede tanı aldığı zaman küratif tedavi şansı olan bir tümördür. Lokal ileri evre tümörlerin \%26'sında ilk 2 yıl içerisinde uzak metastaz saptanır. Tümörün en sık metastaz yaptığı yerler akciğer, karaciğer ve kemiktir (3). Özofagus kanserinin memeye metastazı nadir görülmektedir (3). Literatürde özofagus SCC'de memeye metastaz olarak bildirilen olgu sayısı dörttür. Olguların biri erkek, diğer üçü kadın; yaş aralığı 35-51 idi $(2,3,6)$.

Meme tümörlerinin \%0.4-6.6'sin1 memeye metastaz yapmış maligniteler oluşturmaktadır. Yoğun fibröz dokusu ve zayıf kanlanmas1 nedeni ile memeye metastaz nadir görülmektedir (7). Memeye en s1k metastaz yapan tümörler olarak lenfoma, melanom ve rabdomyosarkom bildirilmiştir (2). Tedavi yönetiminin farklı olması nedeni ile memenin primer ve metastatik lezyonlarının ayrımı önemlidir (6). Memeye metastaz yapan tümörlerin klinik ve radyolojik bulguları heterojendir (3).

Literatürde bildirilen özofagus kanserinin memeye metastaz yapmış olguların çoğu, primer meme kanseri görülme yaşına göre daha genç hastalardan oluşmaktadır (7). Bunun nedeni olarak, genç erişkinlerde meme dokusunda kan akım hızının fazla olması gösterilmektedir (2). Metastatik lezyon genellikle tek, ağrısız, hareketli, tek taraflı, iyi sınırlı ve üst kadran yerleşimlidir (2). Bizim olgumuzda, memede tek, ağrısız lezyon mevcuttu, literatürde bildirilenin aksine tümör alt kadran yerleşimli idi. Memedeki lezyon yaygın hastalığa eşlik edebileceği gibi ilk belirti olarak karşımıza çıkabilir. Nitekim Norooz ve ark.'nın bildirdiği olguda 35 yaşında kadın hastanın ilk başvuru şikayeti memede ele gelen $4 \mathrm{~cm}$ ağrilı kitleydi. Fakat hastanın detaylı öyküsünde, hastanın önemsemediği 2 aydır olan yutma güçlügü mevcuttu (2). Meme lezyonunun mammografik görüntülemesinde mikrokalsifikasyon veya ciltte kalınlaşma gözlenmez (2).

Lokal tedavi sonrasında nüks gözlenen özofagus kanserinin prognozu kötüdür. Küratif cerrahi sonrası lokal veya uzak nüks saptanan olgularda 5 yıllık genel sağkalım (OS) oranları \%20-36 arasında değişmektedir. Özofagus kanserinin meme metastazı kötü prognozludur (8). Hastaların çoğunluğunda ortalama OS bir yıldan kısadır. Vücudun başka yerinde metastaz olmamas1 veya kontrol altına alınması durumunda cerrahi rezeksiyon uygulanabilir (9). Santeufemia ve ark.'nın bildirdiği özofagus kanserli olguda izole meme ve beyin metastazı saptanmıştır. Olguya uygulanan lokal tedaviler (cerrahi ve RT) 
ve sistemik kemoterapi sonrası 11 yıllık OS süresi gözlenmiştir (3). Nüks olgularda cerrahi, kemoterapi veya RT uygulamalarının yararı gösterilmiştir (10). Palyatif kemoterapi olarak s1kl1kla sisplatin ve 5-florourasil içeren kombine rejimler kullanılmaktadır. Bu kemoterapi rejimleri ile $\% 20-50$ oranında tedavi yanıtları bildirilmektedir (11).

Bizim olgumuzda akciğer, intraabdominal lenf nodları ve meme metastazı olmak üzere yaygın nüks hastalık saptandı ve palyatif amaçlı kemoterapi başlandı. Tümörün agresif seyirli olması ve kemoterapiye duyarsiz olması nedeni ile hasta 8 ay içinde yaşamını yitirdi. Özofagus kanserinin her organ ve dokuya metastaz yapabileceği akılda tutulmalı ve bu nedenle hasta takibinde sistemik muayene içinde meme muayenesi de yapılmalıdır.

\section{Çıkar Çatışması: Yok}

\section{Kaynaklar}

1. Iwanski GB, Block A, Keller G, et al. Esophageal squamous cell carcinoma presenting with extensive skin lesions: a case report. J Med Case Reports 2008;2:115

2. Norooz MT, Montaser-Kouhsari L, Ahmadi H, Zavarei MJ, Daryaei P. Breast mass as the initial presentation of esophageal carcinoma: a case report. Cases J 2009;2:7049

3. Santeufemia DA, Piredda G, Fadda GM, et al. Successful outcome after combined chemotherapeutic and surgical management in a case of esophageal cancer with breast and brain relapse. World J Gastroenterol 2006;12:5565-8

4. Edge SB, Byrd DR, Compton CC. Esophagus and Esophagogastric Junction. In: AJCC Cancer Staging Manuel.7 th ed. NewYork: Springer 2009:103-15

5. Tuncer İ, Uygan İ, Kösem M, ve ark. Van ve Çevresinde Görülen Üst Gastrointestinal Sistem Kanserlerinin Demografik ve Histopatolojik Özellikleri. Van Tıp Derg 2001;8:10-3

6. Miyoshi K, Fuchimoto S, Ohsaki T, et al. A Case of Esophageal Squamous Cell Carcinoma Metastatic to the Breast. Breast Cancer 1999;6:59-61

7. Silverman JF, Feldman PS, Covell JL, Frable WJ. Fine needle aspiration cytology of neoplasms metastatic to the breast. Acta Cytol 1987;31:291-300

8. Ribeiro-Silva A, Mendes CF, Costa IS, de Moura HB, Tiezzi DG, Andrade JM. Metastases to the breast from extramammary malignancies: a clinicopathologic study of 12 cases. Pol J Pathol 2006;57:161-5

9. Shiraishi M, Itoh T, Furuyama K, et al. Case of metastatic breast cancer from esophageal cancer. Dis Esophagus 2001;14:162-5

10. Saeki H, Kawaguchi H, Araki K, Ohno S, Sugimachi K. Treatment strategy for and clinical results in patients with recurrent esophageal cancer . Nihon Geka Gakkai Zasshi 1999;100:185-90

11. Leichman L, Berry BT. Experience with cisplatin in treatment regimens for esophageal cancer.Semin Oncol 1991;18:64-72 